\title{
Assessment of ventilatory function in patients with spinocerebellar ataxia type 2
}

\author{
Avaliação da função ventilatória em pacientes com ataxia espinocerebelar tipo 2 \\ Neliana Maria de MELLO', Marise Bueno ZONTA2,3, Hélio Afonso Ghizoni TEIVE2,3, Alex Tiburtino MEIRA², \\ Francisco Diego Negrão LOPES NETO 4 , Janaina Turcato da Silva Nonato da SILVA5 ${ }^{5}$ Carlos Henrique \\ Ferreira CAMARGO3 ${ }^{3}$ Bianca Simone ZEIGELBOIM
}

\begin{abstract}
Subclinical ventilatory dysfunction is observed in individuals with spinocerebellar ataxias (SCA). No studies have correlated ventilatory dysfunction to clinical and functional decline in SCA2. Objective: To evaluate the relationship between the values of peak expiratory flow (PEF), maximum inspiratory pressure (MIP), and presence of respiratory complaints with age, disease duration, age at onset of symptoms, balance scores, independence in basic (ADL) and instrumental (IADL) Activities of Daily Living (ADLs), and severity of ataxia (SARA) in individuals with SCA2. Methods: Cross-sectional study evaluating age, disease duration, age at onset of symptoms, scores in the Berg Balance Scale and in the SARA, Functional Independence Measure and Lawton's scale, values of PEF and MIP, and the presence of respiratory complaints. Results: The study included 36 individuals with SCA2, with a mean age of $42.5 \pm 2.4$ years, disease duration of $7.6 \pm 8.2$ years, age $33.7 \pm 11.5$ years at onset of symptoms, and $9.9 \pm 10.3$ points in the SARA scale. The lowest PEF values correlated with the longer disease duration $(p=0.021)$. The lowest values of PEF and MIP correlated with greater balance impairment ( $p=0.019$ and $p=0.045$, respectively), increased degree of dependence in the $A D L$ ( $p=0.006$ and $p=0.050$, respectively) and IADL ( $p=0.003$ and $p=0.001$, respectively) scales, and highest severity of ataxia ( $p=0.006$ and $p=0.017$, respectively). Respiratory complaints were observed in 12 (33.3\%) individuals and were not related to age, disease duration, age at onset of symptoms, balance, independence, ataxia severity, or PEF and MIP values. Conclusion: Ventilatory dysfunction, even when asymptomatic, is related to balance impairment, independence, and ataxia severity in individuals with SCA2.
\end{abstract}

Keywords: spinocerebellar ataxia; peak expiratory flow rate; maximum inspiratory pressure; postural balance; functional independence; disease severity index.

RESUMO

Disfunção ventilatória subclínica tem sido observada em indivíduos com ataxias espinocerebelares (SCA). Não existem estudos relacionando disfunção ventilatória ao declínio clínico e funcional na SCA2. Objetivo: Avaliar a relação dos valores de Pico de Fluxo Expiratório (PFE), Pressão Inspiratória Máxima (PIMAX) e presença de queixas respiratórias com idade, tempo de doença, idade de início dos sintomas, escore de equilíbrio, independência para atividades básicas (AVD) e instrumentais (AIVD) de vida diária e gravidade da ataxia (SARA) em indivíduos com SCA2. Métodos: Estudo transversal, considerando: idade, tempo de doença, idade de início dos sintomas, escores nas Escalas SARA, Equilíbrio de Berg, Medida da Independência Funcional e de Lawton, valores de PFE, PIMAX e queixas respiratórias. Resultados: Foram avaliados 36 indivíduos com SCA2 com média de 42,5 $\pm 2,4)$ anos de idade, 7,6 $\pm 8,2$ anos

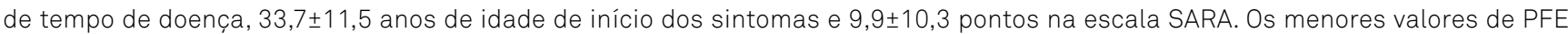
estiveram relacionados ao maior tempo de doença $(p=0,021)$. Os menores valores de PFE e PIMAX estiveram relacionados ao maior comprometimento do equilíbrio ( $p=0,019 ; p=0,045$, respectivamente), maior dependência para $A D V(p=0,006 ; p=0,050$, respectivamente) e AIVD ( $p=0,003 ; p=0,001$, respectivamente) e maior gravidade da ataxia ( $p=0,006 ; p=0,017$, respectivamente). Foram observadas

\footnotetext{
${ }^{1}$ Universidade Federal do Paraná, Hospital de Clínicas, Unidade Multiprofissional, Serviço de Fisioterapia, Curitiba PR, Brazil.

${ }^{2}$ Universidade Federal do Paraná, Hospital de Clínicas, Departamento de Medicina Interna, Serviço de Neurologia, Setor de Distúrbios do Movimento, Curitiba PR, Brazil.

${ }^{3}$ Universidade Federal do Paraná, Hospital de Clínicas, Departamento de Medicina Interna, Programa de Pós-Graduação em Medicina Interna (Neurologia), Curitiba PR, Brazil.

«Universidade Federal do Paraná, Hospital de Clínicas, Serviço de Estatística, Curitiba PR, Brazil.

${ }^{5}$ Hospital Zilda Arns, Serviço de Fonoaudiologia, Curitiba PR, Brazil.

${ }^{6}$ Universidade Tuiuti do Paraná, Departamento de Otoneurologia, Curitiba PR, Brazil.
}

Neliana Maria de MELLO iD https://orcid.org/0000-0001-7776-4234; Marise Bueno ZONTA iD https://orcid.org/0000-0003-1652-7723; Hélio Afonso Ghizoni TEIVE (iD https://orcid.org/0000-0003-2305-1073; AlexTiburtino MEIRA iD https://orcid.org/0000-0002-6685-7491; Francisco Diego Negrão LOPES NETO iD https://orcid.org/0000-0003-2094-5928;Janaína Turcato da Silva Nonato da SILVA iD https://orcid.org/0000-0002-7258-5146;

Carlos Henrique Ferreira CAMARGO iD https://orcid.org/0000-0002-3533-0347; Bianca Simone ZEIGELBOIM (iD) https://orcid.org/0000-0003-4871-2683 Correspondence: Neliana Maria de Mello; Rua Presidente Rodrigo Otávio, 633 / Sobrado 5; 80045-395 Curitiba PR, Brazil; E-mail: nelimello92@gmail.com Conflict of Interest: There is no conflict of interest to declare.

Received on March 20, 2019; Received in its final form on September 13, 2019; Accepted on September 30, 2019. 
queixas respiratórias em 12 (33,3\%) indivíduos que não estiveram relacionadas à idade, idade de início dos sintomas, tempo de doença, equilíbrio, independência, gravidade da ataxia, ou valores de PFE e PIMAX. Conclusão: A disfunção ventilatória, mesmo quando assintomática, está relacionada ao comprometimento do equilíbrio, à independência e à gravidade da ataxia em indivíduos com SCA2.

Palavras-chave: ataxias espinocerebelares; pico de fluxo expiratório; pressões inspiratórias máximas; equilíbrio postural; independência funcional; índice de gravidade da doença.

Spinocerebellar ataxias (SCAs) are clinical conditions comprising an extensive, complex, and heterogeneous group of neurodegenerative diseases with autosomal dominant inheritance ${ }^{1}$. SCAs occur in different types classified according to gene mutation. At least 48 genetic loci have been associated with SCAs ${ }^{2,3}$. SCA2 - the third most frequent SCA type in Brazil - is a polyglutamine disease caused by abnormal expansion of CAG triplet repetitions in the coding region of the ATXN2 gene (12q24.1) ${ }^{1-3}$.

SCAs comprise a clinically heterogeneous group of diseases characterized by progressive cerebellar dysfunction (mainly gait and limb ataxia) evolving with different degrees of dysarthria, dysmetria, and nystagmus, eventually accompanied by other movement disorders ${ }^{4}$. Clinical manifestations may also include resting or action tremors, polyneuropathy, upper motor neuron involvement, and parkinsonism, which may predominate in some cases $^{5}$. SCA2 is characterized by a progressive cerebellar syndrome that can be accompanied by slowing of horizontal saccadic eye movements ${ }^{4}$. Other commonly described signs and symptoms are cognitive impairment, peripheral neuropathy with fasciculation, and sleep disorder $\mathrm{s}^{5-7}$. Longer disease duration is associated with greater balance impairment, functional dependence, and ataxia severity in subjects with SCA2 ${ }^{8}$.

Sriranjini et al. ${ }^{9}$ showed a prevalence of restrictive pulmonary dysfunction and upper airway obstruction in patients with SCA1, SCA2, and SCA3; compared with controls, these patients presented significantly lower parameters of total lung volume and respiratory muscle strength. The authors observed subclinical pulmonary dysfunction in all subtypes of SCA analyzed, but the correlation between lung function and disease parameters occurred only in patients with SCA3.

Among other factors, the authors attributed the pulmonary dysfunction in SCA to lack of muscle coordination and inability to sustain respiratory effort due to respiratory muscle incoordination. In the study, individuals with SCA1 (n=13) and SCA2 (n=9) were the ones most affected. In addition, progressive bulbar dysfunction can contribute to ventilatory dysfunction ${ }^{10}$.

Based on the considerations above, the aim of this study was to evaluate the relationship between ventilatory function and clinical and functional data in patients with SCA2.

\section{METHODS}

\section{Selection of patients}

We recruited 36 patients with SCA2 who were following up at the Ataxia Outpatient Clinic, Movement Disorders Unit, at the Hospital de Clínicas (Federal University of Paraná; HC-UFPR) between September 2017 and August 2018. The patients had (1) a clinical and genetic diagnosis of SCA2 or (2) clinical features and relatives with genetic confirmation of SCA2. Exclusion criteria were (1) active smoking, (2) uncontrolled hypertension, (3) musculoskeletal disorders that could affect balance and functionality, (4) other concomitant neurological diseases, and (5) absence of regular followup at the outpatient unit.

All participants were informed about the procedures and signed a free and informed consent form. The ethics committee of the HC-UFPR approved this cross-sectional study (CAAE: 70592817.1.0000.0096).

\section{Clinical assessment}

Demographic and clinical variables (age, gender, age at onset of symptoms, disease duration, and use of walking aid) were collected in a standardized fashion. The patients were scored for ataxia severity according to the 8-item Scale for the Assessment and Rating of Ataxia (SARA), which ranges from a total score of 0 (no ataxia) to 40 (most severe ataxia) ${ }^{11}$. All instruments were assessed using the Portuguese versions of the Berg Balance Scale (BBS) ${ }^{12}$, Functional Independence Measure-Activities of Daily Living (FIM-ADL) ${ }^{13}$, and Lawton's Instrumental Activities of Daily Living (IADL) scales ${ }^{14}$. The $\mathrm{BBS}^{12}$ evaluates 14 items related to daily activities involving static and dynamic balance, yielding a maximum score of 56 points. Individuals with scores between 41 and 56 can walk independently (low fall risk), those with scores between 21 and 40 are able to walk with assistance (medium fall risk), and those with scores between 0 and 20 require a wheelchair (high fall risk). The FIM $^{13}$ assesses the degree of independence on 18 items related to Activities of Daily Living (ADLs), including the domains of self-care, transfers, walking, and sphincter control (motor subscale), and communication and social cognition (cognitive subscale). In this study, we considered the motor subscale, which ranges from 13 to 91 points (the higher the score, the greater the individual's independence). Individuals with scores 6 or 7 in all items of the motor subscale were considered to be independent. Lawton's IADL 
scale $^{14}$ assesses independence in seven activities of greater complexity like shopping, preparing meals, and using transportation. The total score varies from 7 to 21 , and the individuals are classified as independent when having a total score of 21 points, partially dependent when having a score between 6 and 20, and dependent when having a score lower than or equal to 5 .

\section{Respiratory evaluation}

During anamnesis, we assessed the occurrence of cough, respiratory infection (upper/lower airway), and dyspnea on mild, moderate, or heavy exertion. $\mathrm{SpO}_{2}$ was measured using the Nonin Onyx ${ }^{\star}$ pulse oximeter (Nonin Medical, Inc., Plymouth, MN, USA). The respiratory rate in one minute was obtained using a digital stopwatch (Stop Watch) at rest to ensure sufficient clinical conditions to perform the respiratory tests. The reference values adopted by the Brazilian Society of Pulmonology and Tisiology are 12 to 22 breaths per minute for the respiratory rate and between 89 to $99 \%$ for the $\mathrm{SpO}_{2}{ }^{15}$.

Peak expiratory flow (PEF) was evaluated with a portable equipment (Mini Wright, Woodley Clinical Trials, Lancashire, UK) and a disposable mouthpiece. The reference values were based on the table by Leiner et al. ${ }^{16}$, validated by the Brazilian Society of Pulmonology and Tisiology ${ }^{15}$. This technique is also recommended to diagnose and monitor ventilatory symptoms in patients with neuromuscular and neurodegenerative diseases, as it verifies the degree of airway obstruction / restriction. The only contraindication for this test is in noncollaborative patients ${ }^{17}$.

Maximum inspiratory pressure (MIP) was measured using an analog pressure manometer (Suporte Classe B, São Paulo, Brazil) calibrated in $\mathrm{cmH}_{2} \mathrm{O}$, with a -120 to $+120 \mathrm{cmH}_{2} \mathrm{O}$ operational limit and a $10-\mathrm{cmH}_{2} \mathrm{O}$ scale, equipped with the same disposable mouthpiece as the one used for PEF measurement. MIP is measured in the obstructed airway (vacuum) at maximum inspiratory effort. The values obtained are negative and reflect the individual's muscle strength: the greater the negativity of the obtained value, the better the muscle strength. This test is used to measure the strength of the respiratory muscles and is useful as a tool in programs to strengthen this musculature and during mechanical ventilation weaning ${ }^{18}$. We used the Black and Hyatt ${ }^{19}$ equation to calculate the normal MIP values for each individual. Three PEF and MIP measurements were obtained, with each individual in the sitting position and supported at 90 degrees, at 2-minute intervals between the tests. The best of the three measurements was recorded and used for the analysis. Both of these measurements involve simple, safe, and low-cost techniques ${ }^{18}$.

\section{Statistical analysis}

The results are presented as means, medians, minimum and maximum values, and standard deviations (quantitative variables) or as frequencies and percentages (categorical variables). The normality of the variables was evaluated with the Shapiro-Wilk test. Student's t-test or the non-parametric Mann-Whitney test were used to compare groups of quantitative variables. Fisher's test was used to compare groups of categorical variables, and Spearman's correlation coefficient to evaluate the association between two quantitative variables. Linear regression was used to assess the relationship between PEF, MIP, and clinical and functional data. P-values $<0.05$ indicated statistical significance. The data were tabulated using Microsoft Excel 2016 and analyzed using JASP v.0.9.2.0.

\section{RESULTS}

Of the 36 individuals with SCA2 participating in the study, 19 (52.8\%) were males. Genetic testing was performed in $13(36.1 \%)$ patients, resulting in a median expansion of the affected allele of 2124 (1648-2354). Table 1 describes the participants' mean age, age at onset of symptoms, disease duration, and scores for independence in the ADL and IADL scales, balance, and disease severity. The PEF values were decreased in 23 (63.9\%) individuals while and MIP values were decreased in 34 (94.4\%) of them (Table 1).

Respiratory manifestations were reported by 12 (33.3\%) individuals, including frequent airway infection in six (16.6\%), dyspnea on exertion reported the IADL and ADL in three $(8.3 \%)$, cough in two $(5.6 \%)$, and snoring in one $(2.8 \%)$ individual. Ten (27.8\%) individuals used walking devices (walker, cane, crutch, or wheelchair), of whom four and six were in the group with and without respiratory complaints, respectively. Participants in the groups with respiratory complaints were older and had more severe scores than those in the group without respiratory complaints ( $\mathrm{p}=$ non-significant). There was no difference between the groups with and without respiratory complaint in relation to MIP and PEF results, degree of independence in the ADL and IADL scales, and impaired balance (Table 1).

PEF showed no correlation with patients' age (rho=-0.181; $\mathrm{p}=0.289$ ), and a moderate correlation with disease duration, ataxia severity, and with the highest degree of balance impairment (Table 2). The highest degree of independence in the ADL and IADL correlated positively and moderately with the higher PEF (Figure 1).

MIP showed no correlation with the patients' age (rho=0.257; $\mathrm{p}=0.131$ ) or disease duration (rho=-0.384; $\mathrm{p}=0.123$ ) and correlated moderately with ataxia severity and greater balance impairment (Table 2). The lowest MIP values correlated negatively and moderately with the highest degree of dependence in the IADL and negatively and strongly with the highest degree of dependence in the IADL (Figure 2). 


\section{DISCUSSION}

Even though initial SCA studies have mostly focused on movement disorders, some have addressed pulmonary function in patients with SCAs and other neurodegenerative diseases like Parkinson's disease (PD) and Huntington's disease $(\mathrm{HD})^{9,20,21}$. Sriranjini et al. ${ }^{9}$ pointed out that the lack of respiratory manifestations in SCA could explain the small number of studies in this area. These authors observed subclinical restrictive pulmonary dysfunction in individuals with ataxia and recommended early management with respiratory physical therapy. We observed reduced PEF and MIP values in our patients with SCA2, a finding that was not related to the patients' age. Correlations between disease duration and decreased PEF values have also been reported. Reductions in PEF and MIP values have been both related to greater balance impairment, increased degree of dependence in the ADL and IADL scales, and greater ataxia severity. Although 33\% of our patients had respiratory complaints, these manifestations were not related to the participants' age, disease duration, or severity of ataxia.

The present study measured PEF values to evaluate the occurrence of respiratory restriction and/or obstruction to the PEF and MIP values to determine the strength of the respiratory muscles. PEF values depend on the expansion of the chest cavity caused by increased lung volume, while MIP is useful to evaluate fatigue ${ }^{22}$. Several authors use PEF and MIP values to quantify the progression of pulmonary
Table 2. Correlations among clinical and functional variables and presence of respiratory findings.

\begin{tabular}{|c|c|c|}
\hline & PEF & MIP \\
\hline Age & $\begin{array}{c}\text { rho }=-0.181,95 \% \mathrm{Cl} \\
(-0.481-0.156) \\
p=0.289\end{array}$ & $\begin{array}{c}\text { rho }=0.257,95 \% \mathrm{Cl} \\
(-0.079-0.540) \\
p=0.131\end{array}$ \\
\hline $\begin{array}{l}\text { Disease } \\
\text { duration }\end{array}$ & $\begin{array}{c}\text { rho }=0,261,95 \% \mathrm{Cl} \\
(-0.633--0.064) \\
p=0.021\end{array}$ & $\begin{array}{c}\text { rho }=-0,384, \\
95 \% \mathrm{Cl} \\
(-0.073-0.543) ; \\
p=0.123\end{array}$ \\
\hline SARA & $\begin{array}{c}\text { rho }=-0.450 \\
95 \% \mathrm{Cl}(-0.678-- \\
0.142) ; p=0.006\end{array}$ & $\begin{array}{c}\text { rho }=0.397,95 \% \mathrm{Cl} \\
(0.078-0.642) \\
p=0.017\end{array}$ \\
\hline IADL & $\begin{array}{c}\text { rho }=0.483,95 \% \mathrm{Cl} \\
(0.184-0.700) \\
p=0.003\end{array}$ & $\begin{array}{c}\text { rho }=-0.521,95 \% \mathrm{Cl} \\
(-0.725--0.232) ; \\
p=0.001\end{array}$ \\
\hline BBS & $\begin{array}{c}\text { rho }=0.389,95 \% \mathrm{Cl} \\
(0.070-0.637) \\
p=0.019\end{array}$ & $\begin{array}{c}\text { rho }=-0.336,95 \% \mathrm{Cl} \\
(-0.009--0.599) ; \\
p=0.045\end{array}$ \\
\hline FIM & $\begin{array}{c}\text { rho }=0.450,95 \% \mathrm{Cl} \\
(0.142-0.678) ; \\
p=0.006\end{array}$ & $\begin{array}{c}\text { rho }=-0.329,95 \% \mathrm{Cl} \\
(-0.594--0.001) ; \\
p=0.050\end{array}$ \\
\hline
\end{tabular}

The Spearman correlation coefficient (rho) was estimated to evaluate the association between two quantitative variables. Values of $p<0.05$ indicate a statistically significant correlation. SARA: Scale for the Assessment and Rating of Ataxia; IADL: Lawton's scale; BBS: Berg Balance Scale; FIM: Measurement of Functional Independence; PEF: peak expiratory flow; MIP: maximum inspiratory pressure.

Table 1. Clinical and functional variables and presence of respiratory findings.

\begin{tabular}{|c|c|c|c|c|c|c|c|c|c|c|}
\hline & \multirow[b]{2}{*}{ Total $n=36$} & \multicolumn{3}{|c|}{ Respiratory complain } & \multicolumn{3}{|c|}{ MIP } & \multicolumn{3}{|c|}{ PEF } \\
\hline & & $\begin{array}{c}\text { With } \\
\text { complaint } \\
n=12\end{array}$ & $\begin{array}{c}\text { Without } \\
\text { complaint } \\
n=24\end{array}$ & $p$-value & $\begin{array}{c}\text { Normal } \\
n=2\end{array}$ & $\begin{array}{c}\text { Altered } \\
n=34\end{array}$ & $p$-value & $\begin{array}{c}\text { Normal } \\
n=13\end{array}$ & $\begin{array}{c}\text { Altered } \\
n=23\end{array}$ & $\mathrm{p}$-value \\
\hline Age & $42.5 \pm 12.4$ & $44.0 \pm 10.0$ & $39.6 \pm 16.4$ & 0.327 (c) & $38.5 \pm 14.8$ & $42.7 \pm 12.5$ & $0.578(c)$ & $42.2 \pm 12.5$ & $42.7 \pm 12.6$ & 0.795(c) \\
\hline $\begin{array}{l}\text { Age of } \\
\text { onset of } \\
\text { symptoms }\end{array}$ & $33.7 \pm 11.5$ & $31.6 \pm 10.5$ & $34.8 \pm 12.0$ & 0.267 (c) & $29.5 \pm 7.8$ & $33.9 \pm 11.7$ & 0.689 (c) & $35.5 \pm 12.6$ & $32.7 \pm 10.9$ & $0.337(\mathrm{c})$ \\
\hline $\begin{array}{l}\text { Gender } \\
\text { (male) }\end{array}$ & $19(52.8 \%)$ & $5(26.3 \%)$ & $14(73.7 \%)$ & $0.483(a)$ & $1(5.3 \%)$ & $18(94.7 \%)$ & $1.0(a)$ & $7(36.8 \%)$ & $12(63.2 \%)$ & $1.0(a)$ \\
\hline $\begin{array}{l}\text { Disease } \\
\text { duration }\end{array}$ & $7.6 \pm 8.2$ & $7.6 \pm 8.4$ & $7.5 \pm 8.2$ & $0.804(c)$ & $9.0 \pm 7.1$ & $7.5 \pm 8.4$ & $0.495(c)$ & $5.7 \pm 7.1$ & $8.7 \pm 8.7$ & $0.214(\mathrm{c})$ \\
\hline SARA & $9.9 \pm 10.3$ & $10.3 \pm 10.5$ & $9.2 \pm 10.3$ & $0.436(c)$ & $10.8 \pm 7.4$ & $9.8 \pm 10.5$ & $0.667(\mathrm{c})$ & $7.4 \pm 7.8$ & $11.3 \pm 11.4$ & $0.344(\mathrm{c})$ \\
\hline IADL & $18.4 \pm 4.2$ & $18.7 \pm 4.1$ & $17.9 \pm 4.6$ & $0.934(\mathrm{c})$ & $19.5 \pm 2.1$ & $18.4 \pm 4.3$ & $0.917(\mathrm{c})$ & $19.4 \pm 3.1$ & $17.9 \pm 4.7$ & $0.474(\mathrm{c})$ \\
\hline BBS & $42.3 \pm 18.2$ & $42.3 \pm 18.0$ & $42.4 \pm 19.6$ & $0.177(\mathrm{c})$ & $48.0 \pm 4.2$ & $42.0 \pm 18.7$ & $0.622(\mathrm{c})$ & $45.2 \pm 16.8$ & $40.7 \pm 19.2$ & $0.673(\mathrm{c})$ \\
\hline FIM & $91 \pm 0$ & $77.6 \pm 22.0$ & $82.4 \pm 11.2$ & 0.540 (c) & $76.0 \pm 2.8$ & $79.4 \pm 19.6$ & $0.229(c)$ & $85.3 \pm 7.1$ & $75.8 \pm 22.7$ & 0.281 (c) \\
\hline MIP & $0.94 \pm 0.23$ & $1 \pm 0$ & $0.9 \pm 0.3$ & $0.5429(\mathrm{a})$ & - & - & - & $0.9 \pm 0.3$ & $1 \pm 0.2$ & $1.0(a)$ \\
\hline PEF & $0.64 \pm 0.49$ & $0.7 \pm 0.5$ & $0.6 \pm 0.5$ & $1.0(a)$ & $0.5 \pm 0.7$ & $0.6 \pm 0.5$ & $1.0(a)$ & - & - & - \\
\hline
\end{tabular}

Data showed as mean \pm standard deviation or median (IQ); a: Fisher's exact test; $\mathrm{p}<0.05$; b: Student's t-test for independent samples; p<0.05; c: non-parametric Mann-Whitney test; $\mathrm{p}<0.05$. SARA: Scale for the Assessment and Rating of Ataxia; IADL: Instrumental Activities of Daily Living; BBS: Berg Balance Scale; FIM: Functional Independence Measure; MIP: Maximum Inspiratory Pressure; PEF: Peak Expiratory Flow. 
dysfunction in patients with neurodegenerative diseases ${ }^{9,14,20}$. In this study, PEF and MIP measurements were obtained with a portable equipment, which could detect the presence of ventilatory disorders in the cohort. This technique has no contraindication, providing that the patient is collaborative, and can even be used in intubated or comatose patients. It is associated with a low cost and provides fast and immediate results. Also, this technique is routinely used to evaluate the efficacy of drug therapy in patients with pulmonary disease $^{17,22}$ and may, in individuals with ataxia, indicate a need for more comprehensive tests like spirometry. Reyes et al. ${ }^{20}$ measured PEF and MIP values using a portable equipment to evaluate lung function in patients with Huntington's disease and also observed a reduction in these parameters in their cohort. Sriranjini et al. ${ }^{9}$ found subclinical respiratory dysfunctions, similar to those observed in other neurodegenerative diseases, namely, restrictive changes and reduced respiratory pressures ${ }^{9}$. Subclinical dysfunction, reflected by reduced MIP and PEF values, is a functional limitation that should be considered, evaluated, and treated when possible.

The reduced MIP and PEF values observed in $94.4 \%$ of our patients corroborate the findings by Sriranjini et al. ${ }^{9}$ These authors evaluated 30 individuals with SCA1, SCA2, and SCA3;
MIP and PEF values were reduced in nine patients with SCA2, which was attributed to lack of coordination of the respiratory muscles. The reduced PEF values observed in $63.9 \%$ of our patients indicate a restrictive pulmonary pattern, which was also observed by Torsney et al. in patients with Parkinson's disease $^{21}$. These authors concluded that respiratory dysfunction occurred due to multiple factors, including restrictive changes and disease severity and duration ${ }^{21}$. We found a correlation between reduced PEF values and disease duration and ataxia severity. The relationship between lower PEF values and longer disease duration corroborates the findings by Sriranjini et al. ${ }^{9}$ However, our MIP values showed no correlation with disease duration, which was also observed by Sriranjini et al. ${ }^{9}$ A possible explanation, in our cohort, could be the shorter disease duration and lower SARA scores. For Charles et al. ${ }^{23}$, the lack of motor coordination between inspiratory and expiratory muscles in neurodegenerative diseases increases respiratory work leading to muscle fatigue. Another factor related to respiratory changes in ataxias is progressive bulbar dysfunction ${ }^{10}$. The natural evolution of SCA2 due to increased cerebellar involvement, as well as greater compromise of brainstem structures may explain the correlation between disease severity and duration with respiratory worsening ${ }^{24}$.
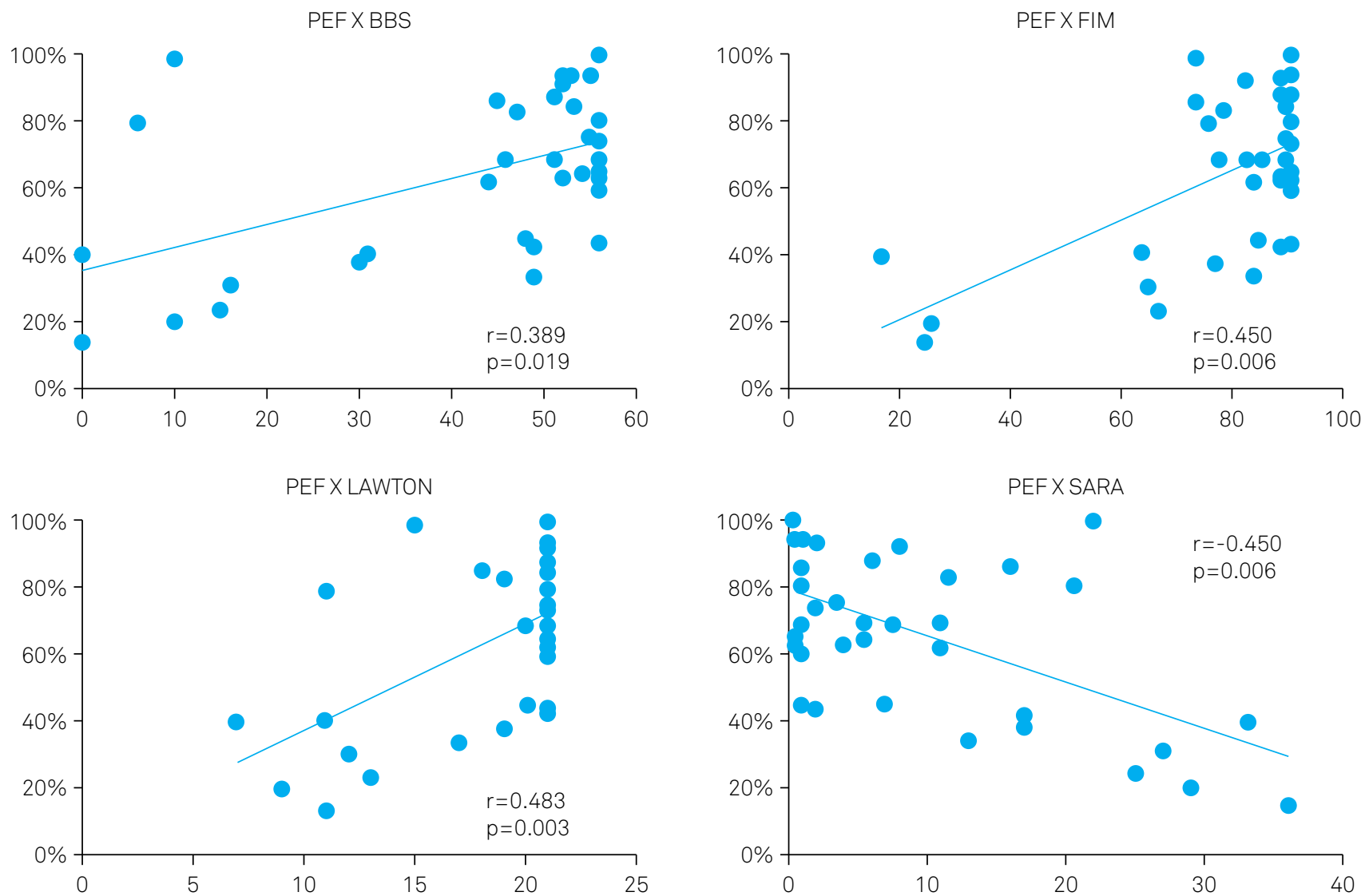

PEF: Peak Expiratory Flow; BBS: Berg Balance Scale; FIM: Measurement of Functional Independence; MIP: maximum inspiratory pressure; IADL: Lawton's Instrumental Activities of Daily Living; SARA: Scale for the Assessment and Rating of Ataxia.

Figure 1. Relationship between Peak Expiratory Flow percentage and scores in the scales Berg Balance Scale, Functional

Independence Measure, Lawton's Instrumental Activities of Daily Living and Scale for the Assessment and Rating of Ataxia. 
Sriranjini et al. ${ }^{9}$ observed an association between ataxia severity and maximum voluntary ventilation values obtained by spirometry for each group of patients with SCA1, SCA2, and SCA3. In the present study, this relationship was observed in a larger group of SCA2 patients using measurements of both MIP and PEF values obtained on an outpatient basis using a portable equipment. Perhaps the measurement of MIP and PEF values during routine outpatient visits may be helpful to monitor the ventilatory condition of individuals with SCA, given the challenges in obtaining these values using more elaborated tests like spirometry. Routine measurements of MIP and PEF values in outpatients with SCA could be used as a screening method to determine which patients require further examination and follow-up.

In the present study, respiratory complaints, including short-term dyspnea, were observed in one-third of the sample. In the study by Sriranjini et al. ${ }^{9}$, no respiratory complaints were observed. Even though the spirometry and measures of ventilatory muscle strength of their cohort had limitations, the authors attributed the lack of respiratory complaints to an adaptation of individuals with ataxia to a less strenuous lifestyle. Different from that study, the present cohort reported complaints of dyspnea, cough, snoring, and frequent respiratory infections, but these complaints were not related to clinical and functional impairment. Perhaps reduced values of PEF and MIP are a safer indication of respiratory abnormalities compared with self-reported complaints.

For Busse et al..$^{25}$, respiratory dysfunction is a common finding in neurodegenerative diseases in which, unfortunately, treatment is characterized as being more supportive than preventive, due to late onset of signs and symptoms. Some studies have addressed the importance of diaphragmatic strengthening in individuals with neurodegenerative diseases. Respiratory muscle training programs led to increased MIP values, cough effectiveness, and improved endurance in individuals with multiple sclerosis and Parkinson's disease ${ }^{26,27}$. According to Callaghan et al. ${ }^{28}$, an understanding of the mechanism of respiratory dysfunction may lead to timely and necessary interventions with the potential to modify and minimize dyspnea complaints, speech and swallowing disorders, respiratory infections, and decreased functional capacity.

The results of genetic tests were only available in a third of our cohort, which prevented the correlation of these data to the study variables, a potential limitation of our study.
MIPXBBS

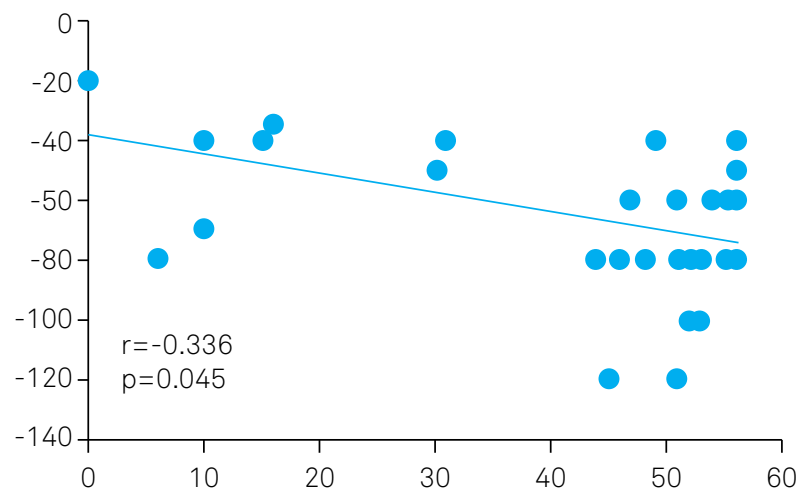

MIPX LAWTON

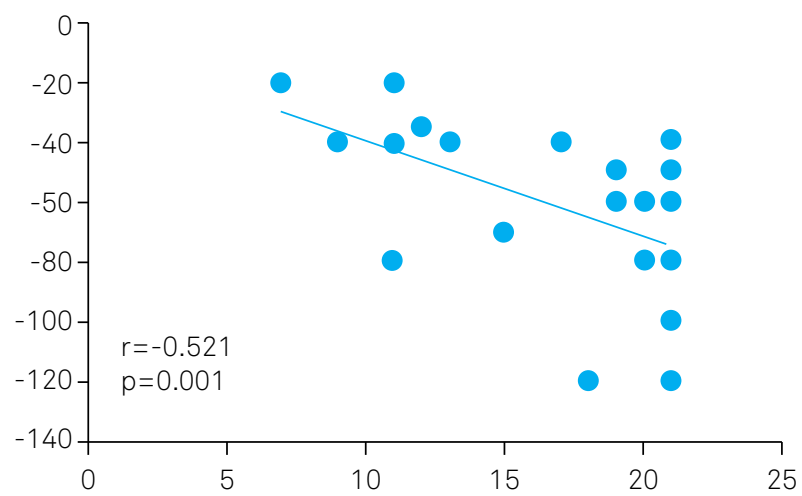

MIPXFIM

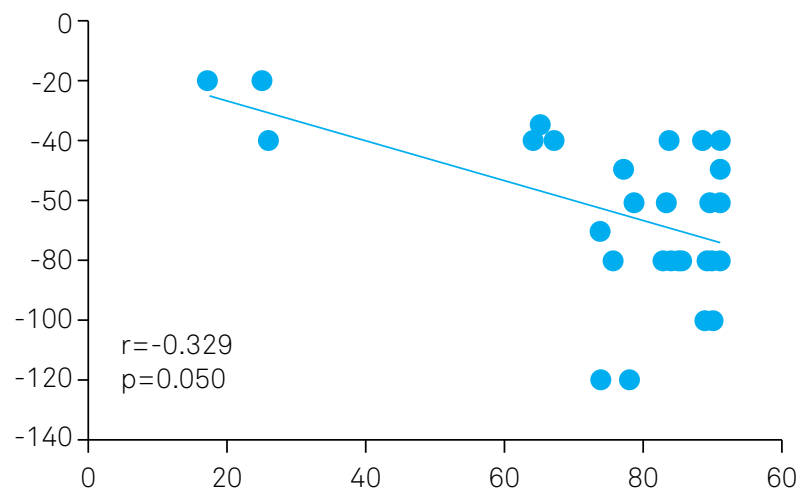

MIPXSARA

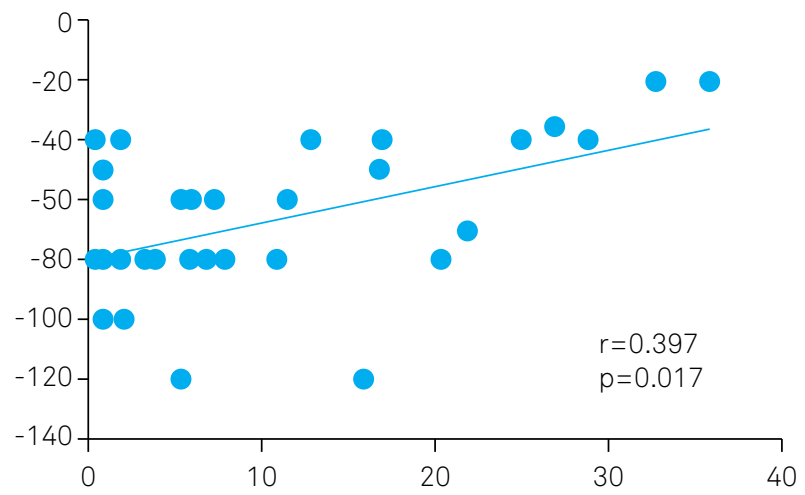

MIP: Maximum Inspiratory Pressure; BBS: Berg Balance Scale; FIM: Measurement of Functional Independence; IADL: Lawton's Instrumental Activities of Daily Living; SARA: Scale for the Assessment and Rating of Ataxia.

Figure 2. Relationship between maximum inspiratory pressure percentages and scores in the scales Berg Balance Scale, Functional Independence Measure, Lawton's Instrumental Activities of Daily Living, and Scale for the Assessment and Rating of Ataxia. 
The decreased disease severity and short disease duration of the patients in our cohort could also be limitations of the present study. On the other hand, the results from the present study may be useful for the implementation of routine evaluations at other services and referral of affected patients to respiratory rehabilitation.

In conclusion, the reduced MIP and PEF values observed in individuals with SCA2 in the present cohort correlated with greater balance impairment, increased degree of dependence on the ADL and IADL scales, and more severe scores in the SARA scale. Reduced PEF values were related to longer disease duration. The presence of respiratory complaints was not related to impaired balance, increased degree of dependence on the ADL and IADL scales, or more severe ataxia. Studies with larger samples are needed to confirm these findings.

\section{References}

1. Teive HA, Ashizawa T. Primary and secondary ataxias. Curr Opin Neurol. 2015 Aug;28(4):413-22. https://doi.org/10.1097/ WC0.0000000000000227

2. Watson LM, Bamber E, Schnekenberg RP, Williams J, Bettencourt C, Lickiss J, et al. Dominant mutations in GRM1 cause spinocerebellar ataxia type 44. Am J Hum Genet. 2017 Sep;101(3):451-8. https://doi. org/10.1016/j.ajhg.2017.08.005

3. Pulst SM, Nechiporuk A, Nechiporuk T, Gispert S, Chen XN, Lopes-Cendes I, et al. Moderate expansion of a normally biallelic trinucleotide repeat in spinocerebellar ataxia type 2. Nat Genet. 1996 Nov;14(3):269-76. https://doi.org/10.1038/ng1196-269

4. Velázquez-Pérez L. An insight into the natural history of spinocerebellar ataxias. Lancet Neurol. 2015 Nov; 14(11):1067-9. https://doi.org/10.1016/S1474-4422(15)00218-5

5. Teive HAG, Munhoz RP, Arruda WO, Lopes-Cendes I, Raskin S, Werneck LC. Spinocerebellar ataxias: genotype-phenotype correlations in 104 Brazilian families. Clinics. 2012;67(5):443-9. http://dx.doi.org/10.6061/clinics/2012(05)07

6. van Gaalen J, Giunti P, Van de Warrenburg BP. Movement disorders in spinocerebellar ataxias. Mov Dis. 2011 Apr;26(5):792-800. https://doi. org/10.1002/mds.23584

7. Shakkottai VF, Fogel BL. Clinical neurogenetics: autosomal dominant spinocerebellar ataxia. Neurol Clin. 2017 Nov;31(4):987-1007. https:// doi.org/10.1016/j.ncl.2013.04.006

8. Amarante TRP, Takeda SYM, Teive HAG, Zonta MB. Impact of disease duration on functional status of patients with spinocerebellar ataxia type 2. Arq Neuropsiquiatr. 2017 Nov;75(11):773-7. https://doi. org/10.1590/0004-282X20170146

9. Sriranjinl SJ, Pal PK, Krishna N, Sathyaprabha TN. Subclinical pulmonary dysfunction in spinocerebellar ataxias 1,2,3. Acta Neurol Scand. 2010 Nov;122(5):323-8. https://doi.org/10.1111/j.1600-0404.2009.01306.x

10. Perlman SL. Symptomatic and disease-modifying therapy for the progressive ataxias. Neurologist. 2004 Sep;10(5):275-89.

11. Schmitz-Hübsch T1, du Montcel ST, Baliko L, Berciano J, Boesch S, Depondt C, et al. Scale for the assessment and rating of ataxia: development of a new clinical scale. Neurology. 2006 Jun;66(11):171720. https://doi.org/10.1212/01.wnl.0000219042.60538.92

12. Miyamoto ST, Lombardi Junior I, Berg KO, Ramos LR, Natour $\mathrm{J}$. Brazilian version of the Berg balance scale. Braz $\mathrm{J}$ Med Biol Res. 2004;37(9):1411-21. http://doi.org/10.1590/S0100$879 \times 2004000900017$

13. Riberto M, Miyazaki MH, Jucá SSH, Sakamoto H, Pinto PPN, Battistella LR. Validação da Versão Brasileira da Medida de Independência Funcional. Acta Fisiatr. 2004 Aug;11(2):72-6. http:// dx.doi.org/10.5935/0104-7795.20040003

14. Santos R, Virtuoso Junior J. Reliability of the Brazilian version of the Scale of Instrumental Activities of Daily Living. RBPS. 2008;21(4):290-6.
15. Sociedade Brasileira de Pneumologia e Tisiologia. Diretrizes da Sociedade Brasileira de Pneumologia e Tisiologia para o Manejo da Asma - 2012. J Pneumol. 2002 Apr;28(Supl. 3):1-238.

16. Leiner GC, Abramowitz S, Small MJ, Stenby VB, Lewis WA. Expiratory peak flow rate. Standard values for normal subjects. Use as a clinical test of ventilatory function. Am Rev Respir Dis. 1963 Nov;88:644-51. https://doi.org/10.1164/arrd.1963.88.5.644

17. Ike D, Cordeiro E, Cutlac-Neto J, Pessoa B, Jamami M. Analysis of agreement between peak expiratory flow meters and comparison of reference values. Fisioter Mov. 2017;30(3):509-17. http://dx.doi. org/10.1590/1980-5918.030.003.ao09

18. Machado MGR. Bases da fisioterapia respiratória: da terapia intensiva a reabilitação. 2. ed. Rio de Janeiro: Guanabara Koogan; 2018.

19. Parreira VF, França DC, Zampa CC, Fonseca MM, Tomich GM, Britto RR. Pressões Respiratórias Máximas. Valores encontrados e preditos em indivíduos saudáveis. Rev Bras Fisioter. 2007;11(5):361-8. http:// dx.doi.org/10.1590/S1413-35552007000500006

20. Reyes A, Ziman M, Nosaka K. Respiratory muscle training for respiratory deficits in neurodegenerative disorders. Chest. 2013 May;143(5):1386-94. http://dx.doi.org/10.1378/chest.12.1442

21. Torsney KM, Forsyth D. Respiratory dysfunction in Parkinson's disease. J R Coll Physicians Edinb. 2017 Mar;47(1):35-39. https://doi. org/10.4997/JRCPE.2017.108

22. Aggarwal AN, Gupta D, Jindal SK. The relationship between FEV1 and peak expiratory flow in patients with airways obstruction is poor. Chest. 2006 Nov;130(5):1454-61. https://doi.org/10.1378/chest.130.5.1454

23. Charles FB, Robert C, Wijdicks EFM, Zifko UA. Neurology of breathing. Philadelphia: Butterworth Heinemann; 2004.

24. Yu Z, Zhu Y, Chen-Plotkin AS, Clay-Falcone D, McCluskey L, Elman L, et al. PolyQ repeat expansions in ATXN2 associated with ALS are CAA interrupted repeats. PLoS One. 2011 Mar 29;6(3):e17951. https://doi. org/10.1371/jounal.pone.0017951

25. Busse ME, Khalil H, Quinn L, Rosser AE. Physical therapy intervention for people with Huntington disease. Phys Ther. 2008 Jul;88(7):820-31. https://doi.org/10.2522/ptj.20070346

26. Jones U, Enright S, Busse M. Management of respiratory problems in people with neurodegenerative conditions: a narrative review. Physiotherapy. 2012 Mar;98(1):1-12. https://doi.org/10.1016/j. physio.2011.03.002

27. Chiara T, Martin AD, Davenport PW, Bolser DC. Expiratory muscle strength training in persons with mild to moderate disability: effect on maximal expiratory pressure, pulmonary function and maximal voluntary cough. Arch Phys Med Rehabil. 2006 Apr;87(4):468-73. https://doi.org/10.1016/apmr.2005.12.035

28. O'Callaghan A, Walker R. Review of pulmonary function in Parkinson's disease. JPRLS. 2018 Apr;8:13-23. https://doi. org/10.2147/JPRLS.S114309 